\title{
Service Quality Assessment using Servqual and Kano Models
}

\author{
Shanty Kusuma Dewi \\ Industrial Engineering Department, University of Muhammadiyah Malang, Indonesia \\ Jalan Raya Tlogomas No.246 Malang, East Java, Indonesia \\ Corresponding author: shanty@umm.ac.id
}

\section{ARTICLE INFO}

\section{Article history}

Received October 28, 2018

Revised February 3, 2019

Accepted February 12, 2019

Available Online February 28, 2019

Keywords

Assessment

Service Quality

Servqual

Kano model

\begin{abstract}
This study aims to assess the quality of services by integrating Servqual and the Kano model. In this study, Servqual is used to determine the quality criteria that must be improved. At this method, the quality criteria are based on the gap between customer perceptions and expectations for the services they receive. Meanwhile, the Kano method is used to categorize service attributes that satisfy customer needs. Servqual integration and the Kano model were carried out by synchronizing the Servqual gap value and the Kano model grade. Assessment of service attributes obtained from both methods produces service attributes that will focus on management's improvement to improve service quality. The results showed that the attribute criteria that must be prioritized were attributes that included attractive and one-dimensional categories, which had weak types at Servqual. Improvements in attributes in attractive and onedimensional categories will improve service quality and increase customer satisfaction.
\end{abstract}

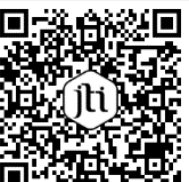

This is an open-access article under the CC-BY-SA license.

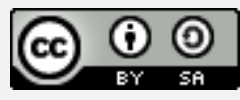

\section{Introduction}

Excellent service quality is based not only on the service provider's perspective but also on service users' perceptions. The service user perception of service quality is a comprehensive assessment of a service [1]. Factors that influence service users' perception include service encounters, evidence of service, company image, and service price. Customer satisfaction is the most crucial factor for the company [2]. Intense competition between companies requires companies to continue to improve their services. Therefore, an analytical model is needed to identify customer needs and assess customer satisfaction. Customer need is the key to service quality and a significant factor in business strategy. Quality of service that can satisfy customers is proven to increase profitability to be a competitive advantage tool. Excellent service quality can create repeat purchases, positive word of mouth, customer loyalty, and competitive service differentiation [3, 4].

Measuring customer satisfaction in this competitive business environment is a must. Organizations that want to meet customers' expectations should use this marketing tool properly [5]. Parasuraman, et al. [6] proposed the gaps model of service quality (Servqual) to represent the differences between customers' expectations and actual 
perceptions to know whether or not customer satisfaction. Measurement of service quality using Servqual has been done in a variety of service industries [7], including the healthcare sector [8-10], banking [11], transportation [12, 13], tourism [14], retailing [15], information systems [16] and library services [17].

Kano classified the service quality attributes according to their effects on customer satisfaction [18-20]. According to this model, attributes impact customer satisfaction in five different categories [21-23]. Such an approach provides the primary guide for companies' strategic and tactical decisions to achieve customer satisfaction. Some research uses the kano model to classified the service quality attributes and customer needs in various service industries [21, 23-28]. However, the ability to measure service quality only constitutes the first step in achieving customer satisfaction. The Kano model [20, 29, 30] identifies the non-linear relationship between attribute performance and customer satisfaction. This research aims to assess the quality of services by integrating Servqual and the Kano model. The integration of Servqual and the Kano model to obtain an appropriate action strategy allows service industry managers to improve service quality and achieve a competitive advantage.

\section{Methods}

\subsection{Proposed Method}

In this research, the value gap from Servqual is conducted to the Kano model. The Servqual kano integration model was adopted from previous studies [31]. However, previous studies it does not consider the kano model's satisfaction level. This research combined the previous model and developed Simultaneous Importance-Performance Analysis (SIPA) and the Kano model [32]. The conceptual model of the integration of the Servqual-kano model in Fig. 1.

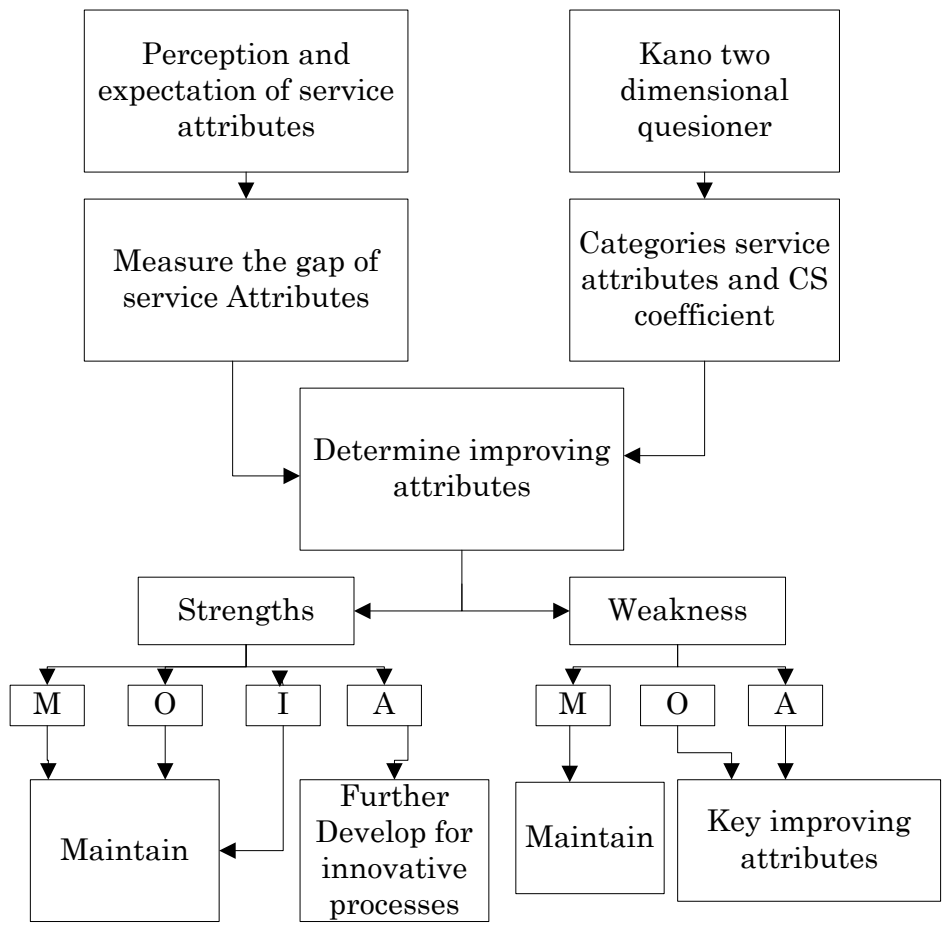

Fig. 1. Conceptual of Servqual Kano Integration Model 
The Servqual methodology, introduced and refined by Parasuraman, et al. [33], represents the most widely applied methodology to measure customers' perceived quality across the service industry, for a review of 20 years of Servqual approaches [7]. Although the Servqual dimension has been empirically tested in many studies, the Servqual dimension is not a pursuit to measure in a retail store environment [34]. Measurement of retail service quality includes five variables: physical aspects, reliability, personal interaction, problem-solving, and policy [35]. Service attributes used are based on several retail store studies [34, 36, 37] and adjust to the research object's conditions (Table 1).

The questionnaire used in this study consisted of three parts. The first part used a 5-point Likert-type scale (from "very disappointed" to "very satisfied") to assess how the perception of customers considered each of the 20 service attributes. The second part used a 5-point Likert-type scale (from "very disappointed" to "very satisfied") to assess how satisfied customers were with the service of the retail store in each of the 20 service attributes. The gap between perceived $(\mathrm{P})$ and expected $(\mathrm{E})$ quality is calculated for each item [15]. The gap between the perceived and expected value of service quality allows assessing the qualitative difference between the customer's image and representing an "ideal" service. The research conducted a pretest of the questionnaire before the formal questionnaire survey to enhance the questionnaire's reliability and validity.

Table 1. Service Attribute in Retail Store

\begin{tabular}{|c|c|}
\hline & Service attributes \\
\hline \multirow{4}{*}{$\begin{array}{l}\text { Physical } \\
\text { Aspects }\end{array}$} & The store has modern-looking equipment and fixtures \\
\hline & The retail store is neat and clean \\
\hline & Material associated with the store's service is visually appealing. \\
\hline & The store layout at this store makes it easy for customers to find what they need \\
\hline \multirow[t]{4}{*}{ Reliability } & The product is looking for is available \\
\hline & The store performs the service right the first time \\
\hline & The store insists on error-free sales transactions and records. \\
\hline & Guarantee of products \\
\hline \multirow{4}{*}{$\begin{array}{l}\text { Personal } \\
\text { Interaction }\end{array}$} & Employees in this store are consistently courteous with customers. \\
\hline & The store offers friendly and polite service \\
\hline & Customers feel safe in their transactions with this store \\
\hline & Employees at the store have the knowledge to answer customers' questions \\
\hline \multirow[t]{3}{*}{$\begin{array}{l}\text { Problem } \\
\text { Solving }\end{array}$} & $\begin{array}{l}\text { Employees of this store can handle customer complaints directly and } \\
\text { immediately }\end{array}$ \\
\hline & $\begin{array}{l}\text { The store gives accurate information related to prices, discounts, product } \\
\text { information }\end{array}$ \\
\hline & The store willingly handles returns and exchanges. \\
\hline \multirow[t]{5}{*}{ Policy } & The price of the products offered are affordable \\
\hline & Opening and closing hours on time \\
\hline & The store accepts various kind of payment (cash, debit, credit card) \\
\hline & The store offers high-quality products \\
\hline & The store provides plenty of convenient parking for its customers \\
\hline
\end{tabular}

The third part was used the Kano model and asked positive- and negativedimension questions for each of the 20 service attributes. The five possible responses were: I like it that way; it must be that way; I am neutral; I can live with it that way; I dislike it that way. The questions had each pair with their perspective responses, as shown in Table 
2. The first question of each pair with the positive dimension questions (Customer's reactions if service provider fulfills the customer's need); the second was negativedimension questions (the customer's responses if the service attribute was unfulfilled).

Table 2. Functional and Dysfunctional Questions in the Kano Questionnaire

$\begin{array}{cl}\text { If the retail Store always neat and clean } & \text { 1. I like it that way } \\ \text { How do you feel? } & \text { 2. It must be that way } \\ \text { (Positive dimension question) } & \text { 3. I am neutral } \\ & \text { 4. I can live with it that way } \\ & \text { 5. I dislike it that way } \\ \text { If the retail store not always neat and } & \text { 1. I like it that way } \\ \text { clean, How do you feel? } & \text { 2. It must be that way } \\ \text { (Negative dimension question) } & \text { 3. I am neutral } \\ & \text { 4. I can live with it that way } \\ & \text { 5. I dislike it that way }\end{array}$

Table 3. Kano Evaluation Table

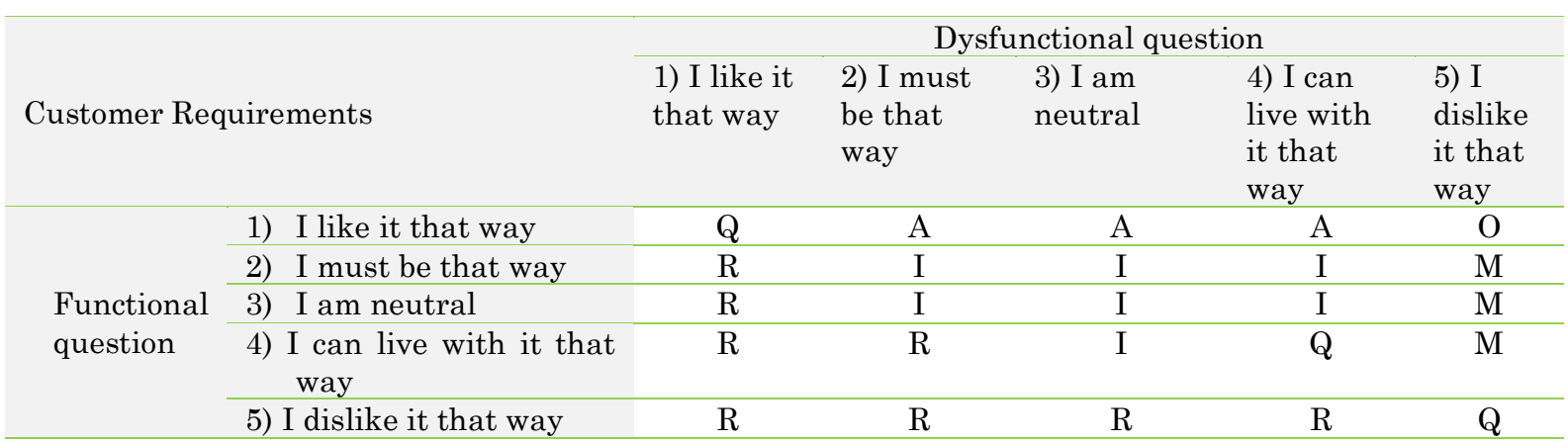

Note A: Attractive, O: One-dimensional, M: Must-be, I: Indifferent, R: Reversal, Q: Questionable.

In this research, classify of service attribute of kano by cross-referencing answer to positive-and negative-dimension questions. The service attributes classify as either "MustBe," "One-Dimensional," "Attractive," "Indifferent," "Reverse," or "Questionable." (Table 3). If a customer answered the positive-dimension question, "I like it that way," and replied, " I dislike it that way," to the negative dimension question. Hence, the service attribute classifies as "one-dimensional." The Kano evaluation table is shown in Table 1 [38]. Service attribute grouping by considering the number of categories each attribute gets. Determination of the Kano category with the following conditions: - If $(O+A+M)>$ $(\mathrm{I}+\mathrm{R}+\mathrm{Q})$ then the maximum grade of $(\mathrm{O}, \mathrm{A}, \mathrm{M})$. - If $(\mathrm{O}+\mathrm{A}+\mathrm{M})<(\mathrm{I}+\mathrm{R}+\mathrm{Q})$, then the grade of the most maximum of $(I, R, Q)$. - If $(O+A+M)=(I+R+Q)$ then the maximum grade among all categories. The consumer satisfaction coefficient can be found with the formula [38]:

$$
\begin{aligned}
& \text { Better }(\mathrm{CS} 1)=\frac{A+O}{A+O+M+I} \\
& \text { Worse }(\mathrm{CS} 2)=-\frac{O+M}{A+O+M+I}
\end{aligned}
$$

Better also known as satisfaction level (CS1), the satisfaction level coefficient ranges from 0 to 1 ; the closer to the value 1, the more it affects customer satisfaction, and vice versa. 2 . Worse are the level of dissatisfaction (CS2). If the deal gets closer to -1, the effect on consumer disappointment is getting stronger, and vice versa. The integration of 
the Servqual and kano model was used to categorize which attribute will concern decisionmakers.

\subsection{Data Collecting}

This research was conducted by surveying 125 respondents who are customers of retail stores in Malang. Table 4 shows the respondents' characteristics, which offer information about gender, age, and purchase frequency.

\section{Result and Discussions}

Based on Table 4, Respondents who were male were $52 \%$, and respondents who were female were $48 \%$. Males tend to gather information through heuristic men and gather salient cues compared to women who believe in in-depth information search. Women are more subjective and intuitive. Males tend to be more analytical and logical who make their opinions based on other people's purchases rather than trying it themselves. Males tend to value quality and efficiency the most, while women value emotional connection and relations [39].

Furthermore, where males tend to make purchases based on immediate needs, women took at purchase as a long-term decision. The percentage of respondents based on gender has little difference, so it can be concluded that male respondents can be a measuring tool to measure the level of customer satisfaction with retail store services. Most of the respondents were less than 35 years old, almost $84 \%$ in terms of age. Buyers with an age of fewer than 35 years are more impulsive than those who are above them. Therefore, the strategy for improving the quality of retail store services can be based on potential consumers' needs according to age.

In the gap analysis (Table 5), positive differences between expectations and perceptions indicate strengths, whereas negative differences indicate service quality weaknesses [31]. In this context, data collected from 125 respondents were analyzed, and found that 12 service attributes were negative. Eight service attributes had a positive gap. The service attribute with the most significant gap value is "Employees of the store can handle customer complaints directly and immediately" Furthermore, the attribute that has the most significant positive gap is "Guarantee of products." The negative dimension value or the most significant gap occurs in the personal interaction and problem-solving dimension. These indicated that the customer thinks that the company has not paid attention to customers by providing good personal interaction and not solving customer problems. Excellent service quality leads to customer loyalty, as it increases customer confidence towards and satisfaction with the company. It is supposed that positive perceptions of service quality enhance customers' possibility of supporting the company and strengthening loyalty behavior [40].

Table 4. Background of respondents demographic characteristic

\begin{tabular}{|c|c|c|c|}
\hline Variable & Item & Respondent & Percentage \\
\hline \multirow{2}{*}{ Gender } & Male & 65 & $52 \%$ \\
\hline & Female & 60 & $48 \%$ \\
\hline \multirow{3}{*}{ Age } & 25 or below & 57 & $46 \%$ \\
\hline & $26-35$ & 48 & $38 \%$ \\
\hline & 36 Or above & 20 & $16 \%$ \\
\hline \multirow{3}{*}{ Purchase frequency } & 1 & 7 & $6 \%$ \\
\hline & $2-5$ & 48 & $38 \%$ \\
\hline & Six or above & 70 & $56 \%$ \\
\hline
\end{tabular}


Table 5. Service Quality Gap

\begin{tabular}{|c|c|c|c|c|c|}
\hline Code & Service attributes & $\begin{array}{l}\text { Perceived } \\
\text { Quality }\end{array}$ & $\begin{array}{l}\text { Expected } \\
\text { Quality }\end{array}$ & GAP & Category \\
\hline 1 & $\begin{array}{l}\text { The store has modern-looking } \\
\text { equipment and fixtures }\end{array}$ & 3.76 & 4.11 & -0.35 & Weak \\
\hline 2 & The retail store is neat and clean & 4.1 & 4.03 & 0.07 & Strong \\
\hline 3 & $\begin{array}{l}\text { The store layout at this store makes it } \\
\text { easy for customers to move around }\end{array}$ & 3.58 & 3.94 & -0.36 & Weak \\
\hline 4 & $\begin{array}{l}\text { The store layout at this store makes it } \\
\text { easy for customers to find what they } \\
\text { need }\end{array}$ & 3.52 & 4.12 & -0.6 & Weak \\
\hline 5 & $\begin{array}{l}\text { The product you are looking for is } \\
\text { available }\end{array}$ & 4.22 & 4.21 & 0.01 & Strong \\
\hline 6 & $\begin{array}{l}\text { The store performs the service right } \\
\text { the first time. }\end{array}$ & 4.02 & 4.26 & -0.24 & Weak \\
\hline 7 & $\begin{array}{l}\text { The store insists on error-free sales } \\
\text { transactions and records. }\end{array}$ & 4.1 & 4.28 & -0.18 & Weak \\
\hline 8 & Guarantee of products & 4.32 & 4.21 & 0.11 & Strong \\
\hline 9 & $\begin{array}{l}\text { Employees in this store are } \\
\text { consistently courteous with } \\
\text { customers. }\end{array}$ & 3.71 & 4.1 & -0.39 & Weak \\
\hline 10 & $\begin{array}{l}\text { The store offers friendly and polite } \\
\text { service }\end{array}$ & 3.56 & 4.01 & -0.45 & Weak \\
\hline 11 & $\begin{array}{l}\text { Customers feel safe in their } \\
\text { transactions with this store }\end{array}$ & 4.04 & 4.26 & -0.22 & Weak \\
\hline 12 & $\begin{array}{l}\text { Employees at the store have the } \\
\text { knowledge to answer customers' } \\
\text { questions. }\end{array}$ & 3.75 & 4.24 & -0.49 & Weak \\
\hline 13 & $\begin{array}{l}\text { Employees of the store can handle } \\
\text { customer complaints directly and } \\
\text { immediately }\end{array}$ & 2.52 & 4.1 & -1.58 & Weak \\
\hline 14 & $\begin{array}{l}\text { The store willingly handles returns } \\
\text { and exchanges. }\end{array}$ & 3.72 & 4.35 & -0.63 & Weak \\
\hline 15 & $\begin{array}{l}\text { The store gives accurate information } \\
\text { related to prices, discounts, product } \\
\text { information }\end{array}$ & 3.55 & 3.9 & -0.35 & Weak \\
\hline 16 & $\begin{array}{l}\text { The price of the products offered are } \\
\text { affordable }\end{array}$ & 3.9 & 3.84 & 0.06 & Strong \\
\hline 17 & Opening and closing hours on time & 4.1 & 3.85 & 0.25 & Strong \\
\hline 18 & $\begin{array}{l}\text { The store accepts various kind of } \\
\text { payment (cash, debit, credit card) }\end{array}$ & 4.01 & 3.94 & 0.07 & Strong \\
\hline 19 & The store offers high-quality products. & 4.31 & 4.22 & 0.09 & Strong \\
\hline 20 & $\begin{array}{l}\text { The store provides plenty of } \\
\text { convenient parking for its customers }\end{array}$ & 3.95 & 3.94 & 0.01 & Strong \\
\hline
\end{tabular}

This study identified and classified the service attributed in retail stores using the Kano model and searched for service attributes that could significantly increase customer satisfaction and decrease customer dissatisfaction according to the calculated CS coefficients [41]. The results of the questionnaires administered to the retail store, shown in Table 6. Five attributes were classified as "Must Be" ( this category has to be provided 
to customers, and its presence does not have a significantly positive impact on customer satisfaction). One Dimensional also has five attributes: this service element is positively and linearly correlated to customer satisfaction [24]. The other ten attributes, including "The price of the products offered are affordable", "The store accepts various kinds of payment (cash, debit, credit card)" and so forth, were classified as "Attractive." (These attributes are crucial to customer satisfaction).

Table 6. Kano Category and Customer Satisfaction Coefficient

\begin{tabular}{cccccccccc}
\hline $\begin{array}{c}\text { Service } \\
\text { Attribute }\end{array}$ & $\mathrm{A}$ & $\mathrm{M}$ & $\mathrm{O}$ & $\mathrm{R}$ & $\mathrm{Q}$ & $\mathrm{I}$ & Category & $\mathrm{CS} 1$ & $\mathrm{CS} 2$ \\
\hline 1 & 30 & 24 & 22 & 21 & 18 & 10 & $\mathrm{~A}$ & 0.60 & $-0,53$ \\
\hline 2 & 49 & 15 & 13 & 25 & 13 & 10 & $\mathrm{~A}$ & 0.71 & $-0,32$ \\
\hline 3 & 41 & 18 & 23 & 18 & 20 & 5 & $\mathrm{~A}$ & 0.74 & $-0,47$ \\
\hline 4 & 27 & 21 & 29 & 16 & 23 & 9 & $\mathrm{O}$ & 0.65 & $-0,58$ \\
\hline 5 & 38 & 16 & 14 & 26 & 27 & 4 & $\mathrm{~A}$ & 0.72 & $-0,42$ \\
\hline 6 & 21 & 34 & 21 & 10 & 19 & 20 & $\mathrm{M}$ & 0.44 & $-0,57$ \\
\hline 7 & 37 & 19 & 27 & 19 & 13 & 10 & $\mathrm{~A}$ & 0.69 & $-0,49$ \\
\hline 8 & 39 & 24 & 25 & 18 & 14 & 5 & $\mathrm{~A}$ & 0.69 & $-0,53$ \\
\hline 9 & 24 & 38 & 21 & 16 & 18 & 8 & $\mathrm{M}$ & 0.49 & $-0,65$ \\
\hline 10 & 33 & 26 & 35 & 14 & 11 & 6 & $\mathrm{O}$ & 0.68 & $-0,61$ \\
\hline 11 & 30 & 21 & 34 & 23 & 5 & 12 & $\mathrm{O}$ & 0.66 & $-0,57$ \\
\hline 12 & 31 & 16 & 37 & 22 & 7 & 12 & $\mathrm{O}$ & 0.71 & $-0,55$ \\
\hline 13 & 14 & 15 & 60 & 14 & 4 & 18 & $\mathrm{O}$ & 0.69 & $-0,70$ \\
\hline 14 & 36 & 43 & 25 & 10 & 1 & 10 & $\mathrm{M}$ & 0.54 & $-0,60$ \\
\hline 15 & 37 & 16 & 34 & 10 & 19 & 19 & $\mathrm{~A}$ & 0.67 & $-0,47$ \\
\hline 16 & 33 & 37 & 20 & 11 & 21 & 3 & $\mathrm{M}$ & 0.57 & $-0,61$ \\
\hline 17 & 38 & 27 & 16 & 23 & 11 & 10 & $\mathrm{~A}$ & 0.59 & $-0,47$ \\
\hline 18 & 40 & 21 & 21 & 18 & 7 & 18 & $\mathrm{~A}$ & 0.61 & $-0,42$ \\
\hline 19 & 26 & 36 & 28 & 14 & 4 & 17 & $\mathrm{M}$ & 0.50 & $-0,60$ \\
\hline 20 & 41 & 19 & 29 & 12 & 7 & 17 & $\mathrm{~A}$ & 0.66 & $-0,45$ \\
\hline Overall Means & & & & & & & & 0,63 & $-0,53$ \\
\hline
\end{tabular}

Note CS1: the satisfaction level coefficient; CS2: the level of dissatisfaction coefficient

Those attributes located in the effective improving area were identified (Fig. 2). Based on the mapping results, found that personal interaction was in the effective improving area. The results of the integration of the SERVQUAL and kano models, as shown in Table 7 . There are eight attributes included in the 'key improving attribute.' Attributes that fall into this category can increase customer satisfaction if seen from the negative gap, and the Kano category is attractive or dimensional. The attributes included in the "attractive" and "one-dimensional" category will lead to customer satisfaction when fulfilled and lead to customer dissatisfaction [38]. So, they are both a necessary and sufficient condition for customer satisfaction. Eight attributes fall into the maintenance category. Maintain decision is given to service attributes with strong or weak service quality (servqual) types and "Must be" category. The retail store must provide attributes included in the "Must be" because these attributes are the primary attributes of service quality in customer satisfaction [41]. 


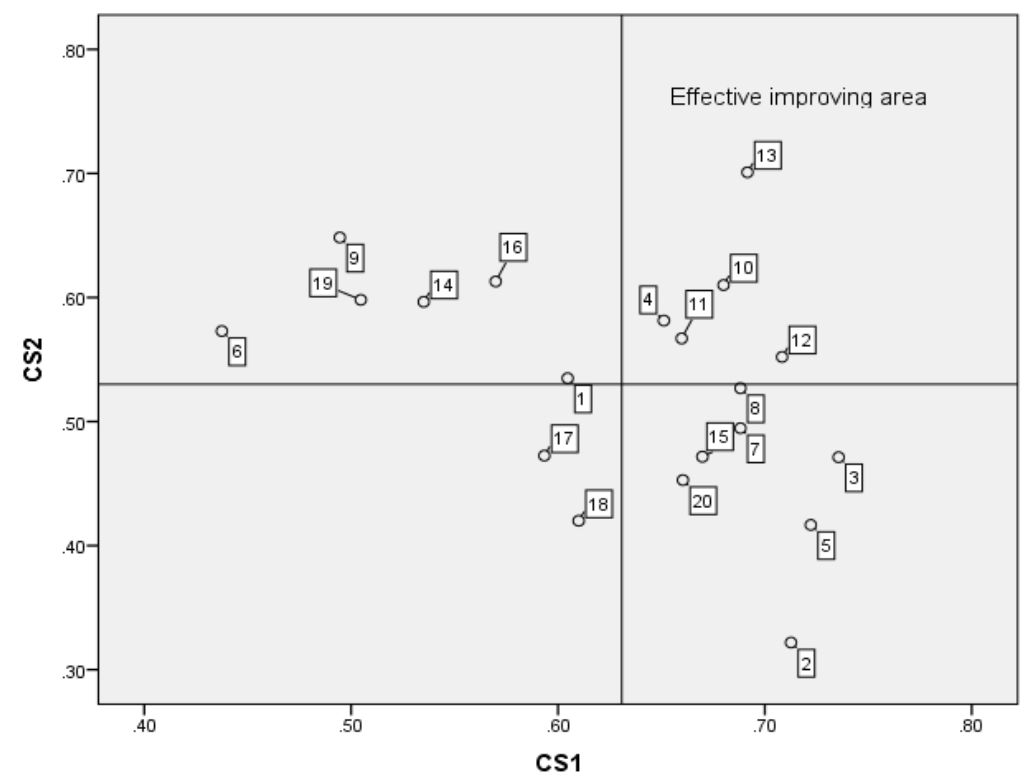

Fig. 2. CS Coefficient Grids Of Retail Store

Table 7. The Result of Servqual and Kano Category

\begin{tabular}{|c|c|c|c|c|c|}
\hline \multirow[b]{2}{*}{$\begin{array}{l}\text { Code } \\
\text { attributes }\end{array}$} & \multicolumn{2}{|c|}{ SERVQUAL } & \multicolumn{2}{|c|}{ KANO } & \multirow[b]{2}{*}{ Decision } \\
\hline & GAP & $\begin{array}{l}\text { Weak or } \\
\text { Strong }\end{array}$ & Category & $\begin{array}{l}\text { Effecting } \\
\text { Improving }\end{array}$ & \\
\hline 1 & -0.35 & Weak & A & & Maintain \\
\hline 2 & 0.07 & Strong & A & & $\begin{array}{l}\text { Further develop for } \\
\text { innovative process }\end{array}$ \\
\hline 3 & -0.36 & Weak & $\mathrm{A}$ & & Key improving attribute \\
\hline 4 & -0.6 & Weak & $\mathrm{O}$ & Yes & Key improving attribute \\
\hline 5 & 0.01 & Strong & A & & $\begin{array}{l}\text { Further develop for } \\
\text { innovative process }\end{array}$ \\
\hline 6 & -0.24 & Weak & $\mathrm{M}$ & & Maintain \\
\hline 7 & -0.18 & Weak & $\mathrm{A}$ & & Key improving attribute \\
\hline 8 & 0.11 & Strong & A & & $\begin{array}{l}\text { Further develop for } \\
\text { innovative process }\end{array}$ \\
\hline 9 & -0.39 & Weak & $\mathrm{M}$ & & Maintain \\
\hline 10 & -0.45 & Weak & $\mathrm{O}$ & Yes & Key improving attribute \\
\hline 11 & -0.22 & Weak & $\mathrm{O}$ & Yes & Key improving attribute \\
\hline 12 & -0.49 & Weak & $\mathrm{O}$ & Yes & Key improving attribute \\
\hline 13 & -1.58 & Weak & $\mathrm{O}$ & Yes & Key improving attribute \\
\hline 14 & -0.63 & Weak & M & & Maintain \\
\hline 15 & -0.35 & Weak & $\mathrm{A}$ & & Key improving attribute \\
\hline 16 & 0.06 & Strong & $\mathrm{M}$ & & Maintain \\
\hline 17 & 0.25 & Strong & $\mathrm{A}$ & & $\begin{array}{l}\text { Further develop for } \\
\text { innovative process }\end{array}$ \\
\hline 18 & 0.07 & Strong & $\mathrm{A}$ & & $\begin{array}{l}\text { Further develop for } \\
\text { innovative process }\end{array}$ \\
\hline 19 & 0.09 & Strong & $\mathrm{M}$ & & Maintain \\
\hline 20 & 0.01 & Strong & A & & $\begin{array}{l}\text { Further develop for } \\
\text { innovative process }\end{array}$ \\
\hline
\end{tabular}




\section{Conclusion}

This study proposed a Servqual Kano integration model to assess the service quality of service providers. The research object is a retail store with five dimensions of service quality: physical aspects, reliability, personal interaction, problem-solving, and policy. The integration model of Servqual kano starts by calculating the value of the gap between perceptions and expectations. Negative gap values are included in the weak type because they cannot satisfy consumers. The kano category results and the mapping of customer satisfaction scores were combined to produce key improving attributes. The service attribute that must be prioritized were attributes that included attractive and onedimensional categories, which had weak types at Servqual. Personal interaction and problem-solving dimensions have to improve their performance and plan for improvement.

\section{References}

[1] A. Gustafsson, M. D. Johnson, and I. Roos, "The effects of customer satisfaction, relationship commitment dimensions, and triggers on customer retention," Journal $\begin{array}{lllll}\text { of } \text { marketing, } & \text { vol. } 69, \quad 210-218, & \end{array}$ https://dx.doi.org/10.1509\%2Fjmkg.2005.69.4.210.

[2] H. Oh, "Service quality, customer satisfaction, and customer value: A holistic perspective," International Journal of Hospitality Management, vol. 18, pp. 67-82, 1999. https://dx.doi.org/10.1016/S0278-4319(98)00047-4.

[3] S. A. Taylor and T. L. Baker, "An assessment of the relationship between service quality and customer satisfaction in the formation of consumers' purchase intentions," Journal of retailing, vol. 70, pp. 163-178, 1994. https://dx.doi.org/10.1016/0022-4359(94)90013-2.

[4] O. Kitapci, C. Akdogan, and I. T. Dortyol, "The impact of service quality dimensions on patient satisfaction, repurchase intentions and word-of-mouth communication in the public healthcare industry," Procedia-Social and Behavioral Sciences, vol. 148, pp. 161-169, 2014. https://dx.doi.org/10.1016/j.sbspro.2014.07.030.

[5] E. Cengiz, "Measuring customer satisfaction: must or not," Journal of Naval Science and Engineering, vol. 6, pp. 76-88, 2010.

[6] A. Parasuraman, V. A. Zeithaml, and L. L. Berry, "Servqual: A multiple-item scale for measuring consumer perc," Journal of retailing, vol. 64, p. 12, 1988.

[7] R. Ladhari, "A review of twenty years of SERVQUAL research," International journal of quality and service sciences, vol. 1, pp. 172-198, 2009. https://dx.doi.org/10.1108/17566690910971445.

[8] M. Muhammad Butt and E. Cyril de Run, "Private healthcare quality: applying a SERVQUAL model," International journal of health care quality assurance, vol. 23, pp. 658-673, 2010. https://dx.doi.org/10.1108/09526861011071580.

[9] H. M. Al-Borie and A. M. Sheikh Damanhouri, "Patients' satisfaction of service quality in Saudi hospitals: a SERVQUAL analysis," International journal of health care quality assurance, vol. 26, pp. 20-30, 2013. https://dx.doi.org/10.1108/09526861311288613.

[10] S. S. Lam, "SERVQUAL: A tool for measuring patients' opinions of hospital service quality in Hong Kong," Total Quality Management, vol. 8, pp. 145-152, 1997. https://dx.doi.org/10.1080/0954412979587.

[11] R. Ladhari, "Assessment of the psychometric properties of SERVQUAL in the Canadian banking industry," Journal of Financial Services Marketing, vol. 14, pp. 70-82, 2009. https://dx.doi.org/10.1057/fsm.2009.2. 
[12] K. Randheer, A. A. Al-Motawa, and P. J. Vijay, "Measuring commuters' perception on service quality using SERVQUAL in public transportation," International Journal of Marketing Studies, vol. 3, p. 21, 2011. https://dx.doi.org/10.5539/ijms.v3n1p21.

[13] Y.-K. Huang, "The Effect of Airline Service Quality on Passengers' Behavioural Intentions Using SERVQUAL Scores," Journal of the Eastern Asia Society for Transportation Studies, vol. 8, pp. 2330-2343, 2010. https://dx.doi.org/10.1016/j.jairtraman.2004.06.001.

[14] S. Raspor, "Measuring Perceived Service Quality Using SERVQUAL: A Case Study of the Croatian Hotel Industry," Management (18544223), vol. 5, 2010.

[15] C. K. Naik, S. B. Gantasala, and G. V. Prabhakar, "Service quality (SERVQUAL) and its effect on customer satisfaction in retailing," European journal of social sciences, vol. 16, pp. 231-243, 2010.

[16] G. J. Udo, K. K. Bagchi, and P. J. Kirs, "Using SERVQUAL to assess the quality of e-learning experience," Computers in Human Behavior, vol. 27, pp. 1272-1283, 2011. https://dx.doi.org/10.1016/j.chb.2011.01.009.

[17] S. Zabed Ahmed and Z. Hossain Shoeb, "Measuring service quality of a public university library in Bangladesh using SERVQUAL," Performance Measurement $\begin{array}{llllll}\text { and } & \text { Metrics, } & \text { vol. } & 10, & \end{array}$ https://dx.doi.org/10.1108/14678040910949666.

[18] E. Sauerwein, F. Bailom, K. Matzler, and H. H. Hinterhuber, "The Kano model: How to delight your customers," in International Working Seminar on Production Economics, 1996, pp. 313-327.

[19] A. O. Paraschivescu and A. COTÎRLEȚ, "Kano Model," Economy Transdisciplinarity Cognition, vol. 15, 2012.

[20] Q. Xu, R. J. Jiao, X. Yang, M. Helander, H. M. Khalid, and A. Opperud, "An analytical Kano model for customer need analysis," Design studies, vol. 30, pp. 87110, 2009. https://dx.doi.org/10.1016/j.destud.2008.07.001.

[21] L.-H. Chen and Y.-F. Kuo, "Understanding e-learning service quality of a commercial bank by using Kano's model," Total Quality Management \& Business $\begin{array}{llllll}\text { Excellence, } & \text { vol. } 22, \quad \text { pp. 99-116, 2011/01/01 } 2011 .\end{array}$ https://dx.doi.org/10.1080/14783363.2010.532345.

[22] T. Wang and P. Ji, "Understanding customer needs through quantitative analysis of Kano's model," International Journal of Quality \& Reliability Management, vol. 27, pp. 173-184, 2010. https://dx.doi.org/10.1108/02656711011014294.

[23] P. Qiting, N. Uno, and Y. Kubota, "Kano Model Analysis of Customer Needs and Satisfaction at the Shanghai Disneyland," ed, 2011.

[24] B. Clegg, T. Wang, and P. Ji, "Understanding customer needs through quantitative analysis of Kano's model," International Journal of Quality \& Reliability Management, 2010. https://dx.doi.org/10.1108/02656711011014294.

[25] N.-T. Kuo, K.-C. Chang, and C.-H. Lai, "Identifying critical service quality attributes for higher education in hospitality and tourism: Applications of the Kano model and importance-performance analysis (IPA)," African Journal of Business $\begin{array}{lllll}\text { Management, } & \text { vol. } \quad \text { 5, } & \text { pp. } & \text { 12016-12024, }\end{array}$ https://dx.doi.org/10.5897/AJBM11.1078.

[26] Y.-F. Kuo, "Integrating Kano's model into web-community service quality," Total Quality Management \& Business Excellence, vol. 15, pp. 925-939, 2004. https://dx.doi.org/10.1080/14783360410001681854.

[27] T. Materla, E. A. Cudney, and J. Antony, "The application of Kano model in the healthcare industry: a systematic literature review," Total Quality Management \& 
Business Excellence, vol. 30, pp. 660-681, 2019/04/03 2019. https://dx.doi.org/10.1080/14783363.2017.1328980.

[28] N. WEN, "Guesthouse customer satisfaction analysis using quantitative kano model," 2015.

[29] J. Mikulić and D. Prebežac, "A critical review of techniques for classifying quality attributes in the Kano model," Managing Service Quality: An International Journal, vol. 21, pp. 46-66, 2011. https://dx.doi.org/10.1108/09604521111100243.

[30] M. M. Rashid, J. i. Tamaki, A. Ullah, and A. Kubo, "A Kano model based linguistic application for customer needs analysis," International Journal of Engineering Business Management, vol. 3, pp. 29-36, 2011. https://dx.doi.org/10.5772\%2F50934.

[31] K. C. Tan and T. A. Pawitra, "Integrating SERVQUAL and Kano's model into QFD for service excellence development," Managing Service Quality: An International Journal, 2001.

[32] H. T. Chen and B. T. Chen, "Integrating Kano model and SIPA grid to identify key service attributes of fast food restaurants," Journal of Quality Assurance in Hospitality \& Tourism, vol. 16, pp. 141-163, 2015. https://dx.doi.org/10.1080/1528008X.2015.1013407.

[33] A. Parasuraman, V. A. Zeithaml, and L. L. Berry, "A conceptual model of service quality and its implications for future research," Journal of marketing, vol. 49, pp. 41-50, 1985. https://dx.doi.org/10.2307/1251430.

[34] N. Y. Siu and J. T. H. Cheung, "A measure of retail service quality," Marketing Intelligence \& Planning, 2001. https://dx.doi.org/10.1300/J046v16n01_05.

[35] P. A. Dabholkar, D. I. Thorpe, and J. O. Rentz, "A measure of service quality for retail stores: scale development and validation," Journal of the Academy of marketing Science, vol. 24, p. 3, 1996. https://dx.doi.org/10.1007/BF02893933.

[36] E. F. Yuen and S. S. Chan, "The effect of retail service quality and product quality on customer loyalty," Journal of Database Marketing \& Customer Strategy Management, vol. 17, pp. 222-240, 2010. https://dx.doi.org/10.1057/dbm.2010.13.

[37] N. Bandyopadhyay, "Prioritising retail service quality determinants: a study in the context of India," International Journal of Business Excellence, vol. 14, pp. 486-498, 2018. https://dx.doi.org/10.1504/IJBEX.2018.090314.

[38] C. Berger, R. Blauth, and D. Boger, "Kanos Methods For Understanding CustomerDefind Quality,” 1993.

[39] S. Bakshi, "Impact of gender on consumer purchase behaviour," Journal of Research in Commerce and Management, vol. 1, pp. 1-8, 2012.

[40] C. M. Veloso, H. Ribeiro, S. R. Alves, and P. O. Fernandes, "Determinants of Customer Satisfaction and Loyalty in the Traditional Retail Service," Economic and Social Development: Book of Proceedings, pp. 470-485, 2017.

[41] F.-Y. Pai, T.-M. Yeh, and C.-Y. Tang, "Classifying restaurant service quality attributes by using Kano model and IPA approach," Total Quality Management \& Business Excellence, vol. 29, pp. 301-328, 2018. https://dx.doi.org/10.1080/14783363.2016.1184082. 